\title{
Prevalence of Beta-Thalassemia Trait Among Students of the University College of Science and Technology-Palestine
}

\author{
Lamia'a Sobhi Saqer*, Mona Ziad Almasri, Shahed Awad Almasri, Zahraa Akram Almasri \\ Medical Sciences Department, University College of Science and Technology, Gaza Strip, Palestine
}

Email address:

Lamiaa1912@yahoo.com (L. S. Saqer)

${ }^{*}$ Corresponding author

\section{To cite this article:}

Lamia'a Sobhi Saqer, Mona Ziad Almasri, Shahed Awad Almasri, Zahraa Akram Almasri. Prevalence of Beta-Thalassemia Trait Among Students of the University College of Science and Technology-Palestine. American Journal of Life Sciences. Vol. 4, No. 2, 2016 , pp. 40-46. doi: 10.11648/j.ajls.20160402.14

Received: March 22, 2016; Accepted: March 31, 2016; Published: April 15, 2016

\begin{abstract}
Thalassemias are a group of recessively inherited genetic disorders mostly common in the Mediterranean, the equatorial and near equatorial regions of Africa and Asia. Large number of mutations cause abnormal globin gene expression and result in complete absence or reduction of globin chain synthesis which lead to thalassemia. $\beta$-thalassemia is the result of deficient or absent synthesis of $\beta$-globin chains, leading to excess $\alpha$ chains. This study was conducted in order to determine the prevalence of $\beta$-thalassemia trait among students of University College of Science and Technology (UCST) in Khan Younis, Gaza Strip-Palestine. Allele Specific PCR (ASPCR) was used to determine the intervening sequence IVSI- $6(\mathrm{~T} \rightarrow \mathrm{C})$ and IVSI$110(\mathrm{G} \rightarrow \mathrm{A})$ mutations. The study population consisted of 348 subjects recruited from the UCST $(144$ males: $41 \%$ and 204 females: 59\%). Blood samples were collected in EDTA tube for CBC. Mentzer index was calculated for all samples. Blood film was done and stained using Giemza stain. DNA was isolated from 12 samples that had normal RBCs and low MCV and whose Mentzer index was $>13$. These samples were subjected to Allele Specific PCR in order to detect IVSI-6 (T $\rightarrow$ C) and IVSI-110 $(\mathrm{G} \rightarrow \mathrm{A})$ mutations. The hemoglobin level in females was found to be about $20 \%$ less than the level recorded in males $(11.40 \pm 1.01$ vs $14.30 \pm 0.79 \mathrm{~g} / \mathrm{dl})$. The results also revealed that there were significant differences in all measured CBC parameters and indices between males and females except that for WBC, RBC, MCHC and PLT. IVSI-6 $(\mathrm{T} \rightarrow \mathrm{C})$ mutation was detected only in two samples and both were heterozygous. IVSI-110 $(\mathrm{G} \rightarrow \mathrm{A})$ mutation was not detected in this study. The present results showed that the case of $\beta$-thalassemia carrier have normal $\mathrm{RBC}, \mathrm{MCH}, \mathrm{Hb}$ and normal Mentzer index which could be missed in routine screening test.
\end{abstract}

Keywords: $\beta$-thalassemia Trait, Allele Specific PCR (ASPCR), Mentzer Index

\section{Introduction}

The term thalassemia is derived from the Greek, thalassa (sea) and haima (blood). Thalassemia refers to a group of inherited blood disorders. They occur most commonly among Asian people especially Southeast Asian, Southern Asian and people of Mediterranean ancestry [1] which was recognized in 1925 for the first time by Tomase Cooley and Lee [2]. The fundamental abnormality in thalassemia is impaired production of the globin chain. Thalassemia can be classified into alpha and beta thalassemias by their clinical manifestations and their genetic background. $\beta$-thalassemia is a common genetic disorder caused by mutations in one or more of the $\beta$-globin gene loci that result in reduced $\beta$-globin production [3].

The human $\beta$-globin gene is part of a multigene family that is expressed in a tissue-specific and developmentally specific manner [4]. The $\beta$-globin chain is encoded by the $H B B$ gene, which spans $1.6 \mathrm{~kb}$ on the short-arm of chromosome 11 (11p15.4) [5]. The genomic sequence of $H B B$ contains three exons, two Intervening Sequences (IVS1 and IVS2) and the 5' and $3^{\prime}$ untranslated regions (UTRs), as shown in Figure 1. The $H B B$ gene is regulated by a $5^{\prime}$ promoter region that contains the classical TATA, 
CAAT and duplicated CACCC boxes (Figure 1a). Upstream of the $\beta$-globin cluster is another regulatory element for $H B B$, namely the locus control region ( $\beta \mathrm{LCR}$ ).

The expression of individual globin genes is governed by direct physical interaction between the $\beta$ LCR and globin promoters, mediated by the binding of tissue-restricted and ubiquitous transcription factors [6].

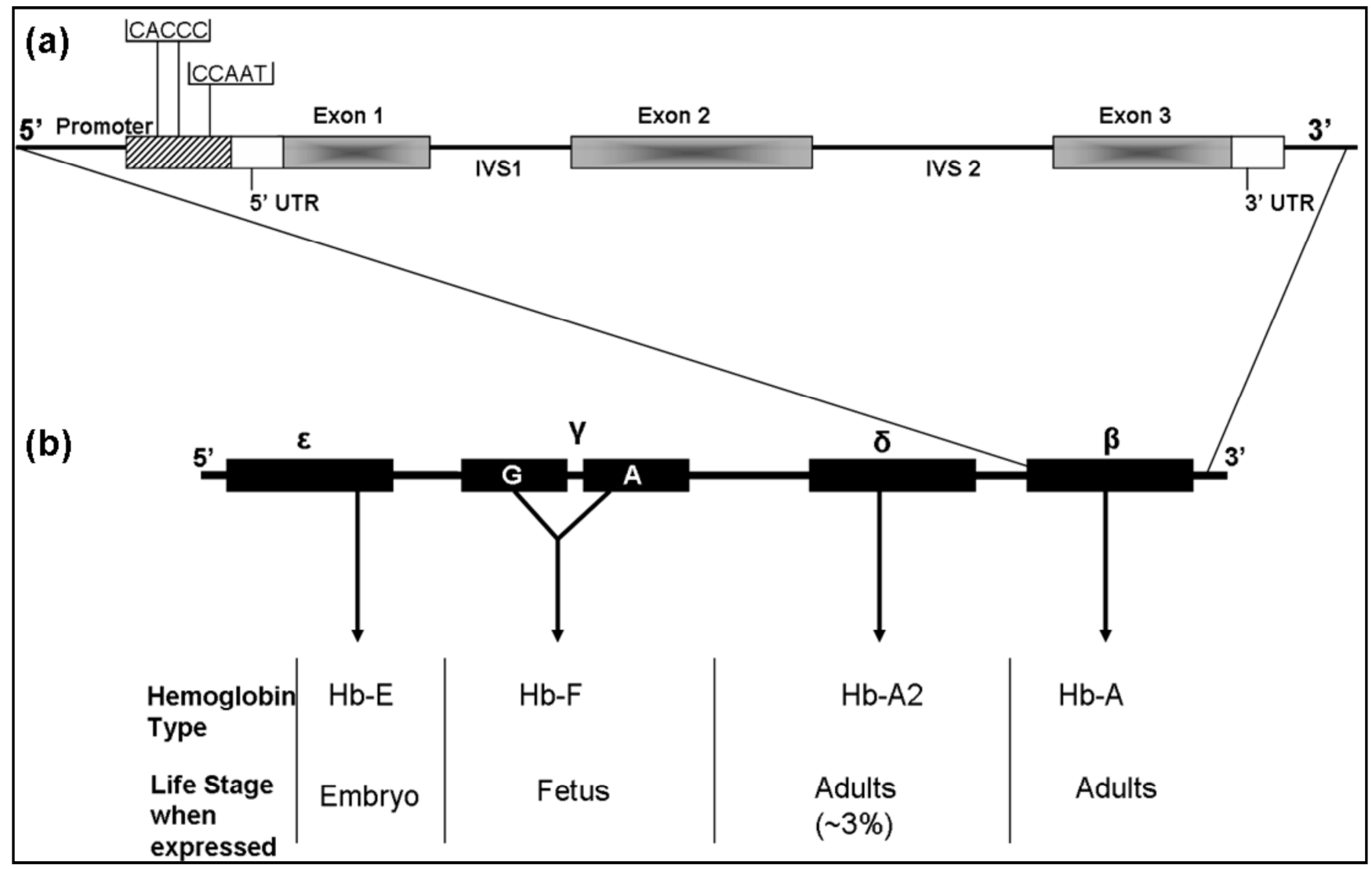

Figure 1. Schematic representations of $\beta$-globin locus: (a) the $\beta$-globin gene with 3 exons and the two IVS (b) the $\beta$-globin locus that resides on chromosome $11 p 15.4$ [7].

Recently, more than 200 different mutations have been detected affecting the diverse levels of $\beta$-globin gene expression and cause $\beta$-thalassemia. These mutations are not uniformly distributed, but have a geographical specificity and racial origin, as each is characterized by the presence of few common mutations and variable numbers of rare ones [5]. Mutations such as nucleotide substitutions and/or frame shifts of the insertion/deletion type have been reported to interfere with the transcription of the $\beta$-globin gene, splicing procedures and translation of $\beta$-globin gene mRNA, resulting in either absence or reduction of synthesis of $\beta$-globin chains [6].

In addition to the direct effects of reduced $\beta$-globin synthesis, many of the symptoms of this disorder appear to be consequences of the resulting cytotoxic buildup of free $\alpha$ globin. Free $\alpha$ - globin is highly unstable and readily precipitates, damaging membrane structures and triggering the apoptotic cell death of erythroid precursors. It has been suggested that such an excess of $\alpha$-chains is the source of oxidative stress $[8,9]$. Clinically, $\beta$-thalassemia are divide into $\beta$-thalassemia major which is homozygous state and $\beta$ thalassemia trait or minor which corresponds to heterozygous state [10].
The significant clinical manifestations and complications commonly associated with $\beta$-thalassemia major are not seen in $\beta$-thalassemia minor. That is, most affected individuals are asymptomatic or characterized clinically by mild anemia with persistent microcytosis that usually goes unnoticed [11].

\section{Methodology}

Blood samples were collected from 348 subjects recruited from students of the University College of Science and Technology Khan Younis, Gaza Strip (UCST). Each sample was collected in EDTA tube. The EDTA samples were kept at $4^{\circ} \mathrm{C}$ and were used within 24 hours for Complete Blood Count (CBC), DNA extraction and subsequent PCR analysis. CBC was performed using Orphee Automatic Hematology Analyzer. Mentzer index was calculated for all samples by dividing $\mathrm{MCV}$ over RBC count. A blood film was prepared from fresh blood sample collected in EDTA tube to evaluate abnormalities in shape and/or size of samples with Mentzer index $(\mathrm{MI})<13$.

Genomic DNA was extracted from blood samples that have low MCV, normal RBCs and MI below13 using Wizard DNA extraction kit (Promega, USA) following the manufacturer's 
instructions from fresh EDTA whole blood cells.

PCR was performed using the primers described by Newton et al. [12]. The nucleotide substitution in the primers was focused on nucleotide position of IVSI-6 and IVSI-110. Four allele specific PCR reactions were carried out for each sample. Primer nucleotide sequences, the primer combination for each reaction and amplification product length are listed in Table 1. For each reaction, $10 \mu \mathrm{l}$ PCR master mix (Promega, USA), $2 \mu$ deionized water, $2 \mu 1$ (100 ng) DNA template and $0.5 \mu \mathrm{l}$ of each allele specific primers $(5 \mathrm{pmol})$ in one micro-tube were mixed. PCR was performed in a thermal cycler (Biometra, Germany). In the first reaction, IVSI-6 $(\mathrm{T} \rightarrow \mathrm{C})$ primer pair was used to amplify the $449 \mathrm{bp}$ fragment to detect the normal alleles. The IVSI-6 $(\mathrm{T} \rightarrow \mathrm{C})$ mutant primer pair in the second reaction was selected to amplify the 286 bp fragment for mutant allele detection. In the third reaction, the IVSI-110 $(\mathrm{G} \rightarrow \mathrm{A})$ primer pair was selected to amplify the $419 \mathrm{bp}$ product to detect normal DNA sequence at this point. Finally in the fourth reaction, the mutant IVSI$110(\mathrm{G} \rightarrow \mathrm{A})$ primer pair was applied to produce the $419 \mathrm{bp}$ fragment to detect the point mutation at this position. In each PCR, specific primers with the sequences:

forward: 5'-GAGTCAAGGCTGAGAGATGCAGGA-3' and reverse: 5'- CAATGTATCATGCCTCTTTGCACC-3')

were used as internal positive control that produces a $861 \mathrm{bp}$ fragment.

The cycling conditions were: an initial denaturation for 3 min at $95^{\circ} \mathrm{C}$, followed by 35 cycles of $60 \mathrm{~s}$ at $94^{\circ} \mathrm{C}, 60 \mathrm{~s}$ at $60^{\circ} \mathrm{C}, 90 \mathrm{~s}$ at $72^{\circ} \mathrm{C}$ and an additional $3 \mathrm{~min}$ at $72^{\circ} \mathrm{C}$ for final extension. Upon completion of PCR, the products were analyzed by electrophoresis on 3\% ethidium bromide stained agarose gel.

Table 1. PCR primers sequence used for $\beta$-globin gene mutation.

\begin{tabular}{|c|c|c|c|}
\hline PCR reaction & Primer pair & Fragment size (bp) & Mutation name \\
\hline 1 & Forward: 5'AGTTGGTGGTGAGGCCCTGGGCAGGTTGGT3' & 449 & Normol IVSI 6 \\
\hline 1 & Revers: 5'CCCCTTCCTATGACATGAACTTAA3' & 449 & Normal IV SI-0 \\
\hline 2 & $\begin{array}{l}\text { Forward: 5'TCTCCTTAAACCTGTCTTGTAACCTTCATG3' } \\
\text { Reverse: 5'ACCTCACCCTGTGGAGCCAC3' }\end{array}$ & 286 & Mutant IVSI-6 \\
\hline 3 & $\begin{array}{l}\text { Forward: 'ACCAGCAGCCTAAGGGTGGGAAAATACACC3' } \\
\text { Reverse: 5'ACCTCACCCTGTGGAGCCAC3' }\end{array}$ & 419 & Normal IVSI-110 \\
\hline 4 & $\begin{array}{l}\text { Forward: 'ACCAGCAGCCTAAGGGTGGGAAAATAGAGT3' } \\
\text { Reverse: 5'ACCTCACCCTGTGGAGCCAC3' }\end{array}$ & 419 & Mutant IVSI-110 \\
\hline
\end{tabular}

\section{Data Analysis}

The data were entered, stored and analyzed by personal computer using the Statistical Package for Social Sciences (SPSS) version 16.0. Independent-Samples T-test and Chi Square Test were used to compare between the two groups of the study (i.e., males and females). P-value $<0.05$ was considered statistically significant.

\section{Results}

The results of our work are presented as cross tabulation tables to illustrate the number and frequencies of the subjects according to the different factors and characteristics. The comparisons between the mean values of the hematological parameters of the two groups were determined using the Ttest analysis and Chi Square.

\subsection{Study Population}

The study population consisted of 348 subjects (144 males, 204 females). The percentage of males was $41.40 \%$ while that of females was $58.60 \%$.

\subsection{General Characteristics of the Study Groups}

There was no significant difference in the mean age of the males $(20.71 \pm 1.60$ years $)$ nor in the females $(20.33 \pm 2.29$ years) of the present work $(\mathrm{P}$-value $=0.091)$. Most of the study population were reside in Khan Younis with $72.90 \%$ $(n=105)$ for males and $72.10 \%(n=147)$ for female (Table 2$)$.
Table 2. General characteristics of the study groups.

\begin{tabular}{|c|c|c|c|c|c|}
\hline Character & \multicolumn{2}{|c|}{ Males n=144 } & \multicolumn{2}{|c|}{ Females $n=204$} & P-value \\
\hline Age (years) & & & & & Independent \\
\hline Mean \pm SD & \multicolumn{2}{|c|}{$20.71 \pm 1.60$} & \multicolumn{2}{|c|}{$20.33 \pm 2.29$} & T-test 0.091 \\
\hline Residence & number & percent & number & percent & \\
\hline Khan Younis & 105 & 72.90 & 147 & 72.10 & \\
\hline Rafah & 28 & 19.40 & 56 & 27.50 & Chi Square \\
\hline $\begin{array}{l}\text { Middle } \\
\text { Prefecture }\end{array}$ & 11 & 7.70 & 1 & 0.50 & Test 0.002 \\
\hline Gaza city & 0 & 0.00 & 0 & 0.00 & \\
\hline
\end{tabular}

\subsection{Hematological Characteristics of the Study Groups}

Table 3. Hematological characteristics of the study groups.

\begin{tabular}{llll}
\hline \multirow{2}{*}{ Parameters } & Male $\mathbf{n}=\mathbf{1 4 4}$ & Female $\mathbf{n}=\mathbf{2 0 4}$ & \multirow{2}{*}{ P-value } \\
\cline { 2 - 3 } & Mean \pm SD & Mean \pm SD & \\
\hline WBC X10 $/ \mathrm{L}$ & $6.44 \pm 1.75$ & $7.37 \pm 1.80$ & 0.925 \\
$\mathrm{RBC} \mathrm{X10} / \mathrm{L}$ & $4.45 \pm 0.33$ & $4.22 \pm 0.39$ & 0.063 \\
$\mathrm{Hb}(\mathrm{g} / \mathrm{dL})$ & $14.30 \pm 0.79$ & $11.40 \pm 1.01$ & 0.020 \\
$\mathrm{HCT}(\%)$ & $38.70 \pm 2.20$ & $36.30 \pm 3.20$ & 0.031 \\
$\mathrm{MCV}(\mathrm{fl})$ & $87.10 \pm 5.50$ & $85.70 \pm 7.40$ & 0.009 \\
$\mathrm{MCH}(\mathrm{pg})$ & $28.70 \pm 2.08$ & $27.00 \pm 2.50$ & 0.019 \\
$\mathrm{MCHC}(\mathrm{g} / \mathrm{dL})$ & $32.70 \pm 2.60$ & $31.30 \pm 1.30$ & 0.418 \\
$\mathrm{PLT} \mathrm{X10} / \mathrm{L}$ & $257.67 \pm 64.50$ & $297.11 \pm 71.15$ & 0.149 \\
$\mathrm{RDW} \%$ & $12.14 \pm 0.90$ & $11.62 \pm 1.35$ & 0.001 \\
\hline
\end{tabular}

WBCs: white blood cells, RBCs: red blood cells, Hb: hemoglobin, HCT: hematocrit, MCV: mean corpuscular volume, $\mathrm{MCH}$ : mean corpuscular hemoglobin, MCHC: mean corpuscular hemoglobin concentration, PLT: platelets count. 
The hematological characteristics of the study groups are shown in Table 3. All CBC parameters and indices measured in the present work revealed significant differences between males and females except that for $\mathrm{WBC}, \mathrm{RBC}, \mathrm{MCHC}$ and PLT. The hemoglobin level in females is found to be about $20 \%$ less than that recorded for males, $11.40 \pm 1.01$ vs $14.30 \pm 0.79 \mathrm{~g} / \mathrm{dL}$, respectively. The MCV and MCH values in females were $85.30 \pm 9.10 \mathrm{fl}$ and $27.00 \pm 2.50 \mathrm{pg}$ compared to $87.10 \pm 5.50 \mathrm{fl}$ and $28.70 \pm 2.08 \mathrm{pg}$ in males. The P-values were 0.009 and 0.019 respectively.

\subsection{Reference Range of Hematological Parameters}

A reference range was obtained following standard guidelines, showing the 2.5-97.5 percentile intervals and median values for each of the hematological parameters determined for the 144 males and 204 females subjects (Table 4).

Table 4. Specific median value and reference interval of the hematological parameters.

\begin{tabular}{|c|c|c|c|c|c|}
\hline \multirow[b]{2}{*}{ Parameter } & \multirow[b]{2}{*}{ Unit } & \multicolumn{2}{|l|}{ Males } & \multicolumn{2}{|l|}{ Females } \\
\hline & & Median & $\begin{array}{l}\text { Reference } \\
\text { interval } \\
(2.5-97.5 \\
\text { percentile) }\end{array}$ & Median & $\begin{array}{l}\text { Reference } \\
\text { interval } \\
(2.5-97.5 \\
\text { percentile) }\end{array}$ \\
\hline WBC & $10^{9} / \mathrm{L}$ & 6.90 & $3.80-11.20$ & 6.90 & $3.80-11.20$ \\
\hline LYM & $\%$ & 35.01 & $20.27-55.48$ & 35.01 & $20.27-55.48$ \\
\hline MON & $\%$ & 7.90 & $4.40-12.13$ & 7.90 & $4.40-12.13$ \\
\hline GRAN & $\%$ & 57.10 & $35.00-74.43$ & 57.10 & $35.00-74.43$ \\
\hline $\mathrm{RBC}$ & $10^{12} / \mathrm{L}$ & 4.42 & $3.90-5.20$ & 4.19 & $3.46-5.07$ \\
\hline $\mathrm{Hb}$ & $\mathrm{g} / \mathrm{dl}$ & 14.30 & $12.70-15.90$ & 11.40 & $9.20-13.20$ \\
\hline HCT & $\%$ & 38.70 & $35.00-43.20$ & 36.50 & $30.10-43.00$ \\
\hline $\mathrm{MCV}$ & $\mathrm{Fl}$ & 87.50 & $66.06-95.60$ & 87.50 & $66.06-95.60$ \\
\hline $\mathrm{MCH}$ & $\mathrm{Pg}$ & 28.10 & $21.10-31.23$ & 28.10 & $21.10-31.23$ \\
\hline $\mathrm{MCHC}$ & $\%$ & 32.10 & $28.70-34.60$ & 32.10 & $28.70-34.60$ \\
\hline PLT & $10^{9} / \mathrm{L}$ & 278.00 & $\begin{array}{l}159.72- \\
453.75\end{array}$ & 278.00 & $\begin{array}{l}159.72- \\
453.75\end{array}$ \\
\hline
\end{tabular}

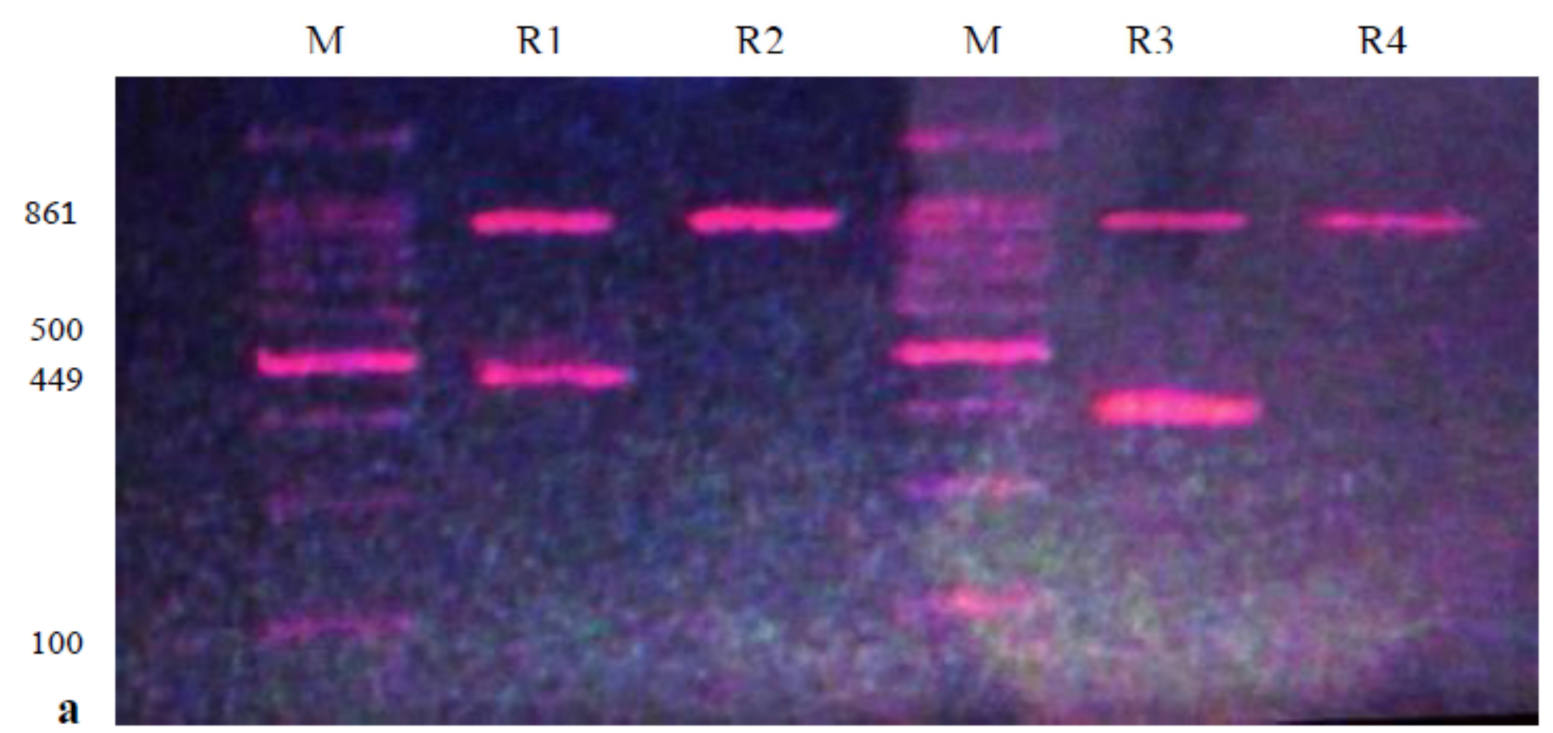

\subsection{RBCs Morphology}

We evaluated the morphology of blood cells in 12 subjects with normal RBCs count and low MCV. Hypochromic and microcytosis were observed in 11 of the 12 subjects $(91.67 \%)$. Normal shape and cell size were noticed in only one subject $(8.33 \%)$. The results related to microcytic hypochromic mean of $\mathrm{Hb}, \mathrm{RBCs}, \mathrm{MCV}$ and $\mathrm{MCH}$ were $10.90 \pm 0.90,3.65 \pm 0.41$, $75.60 \pm 6.60$ and $24.00 \pm 2.20$ respectively.

\subsection{Mentzer Index of the Study Groups}

The best index that showed the distinction between iron deficiency anemia and minor thalassemia was Mentzer (MI). The mean of MI of all samples was 20.63 and 19.72 for males and females respectively, $\mathrm{P}$-value $=0.022$.

\subsection{PCR Results}

Detection of $\beta$ globin gene mutation by Allele Specific PCR

Table 1 showed products of Allele Specific PCR assay. Only 12 samples were used for PCR which have normal RBCs count with high MCV for detection of mutation at IVSI-6 and IVSI-110 position. IVSI-6 $(\mathrm{T} \rightarrow \mathrm{C})$ mutation was observed only in two samples, while IVSI-110 $(\mathrm{G} \rightarrow \mathrm{A})$ mutation was not observed in this study (Table 5).

Table 5. PCR products according to the type of mutation.

\begin{tabular}{llll}
\hline Type of mutation & \multicolumn{4}{l}{ PCR Reactions } & Genotype \\
\hline \multirow{3}{*}{ IVSI-6 } & R1 & R2 & \\
& 449 & 286 & Heterozygous \\
\multirow{2}{*}{ IVSI-110 } & 449 & - & Homozygous normal \\
& R3 & R4 & \\
& 419 & - & Homozygous normal \\
\hline
\end{tabular}

We determined IVSI-6 mutation only in one allele of two subjects from all molecular investigated samples. All other subjects were homozygous normal for IVSI-110 (Figure 2). 


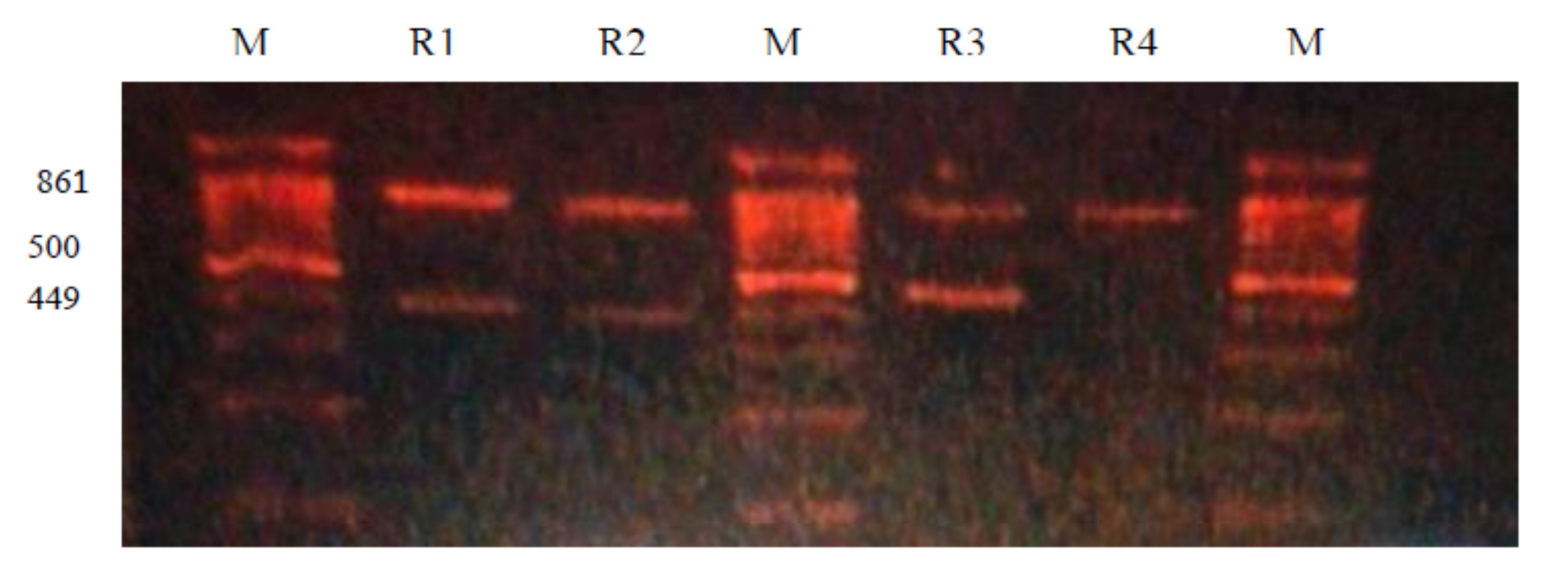

b

Figure 2. The electrophoresis pattern of recognized genotypes using the ASPCR method. Lane M indicates the 100 bp ladder. The R1 - R4 lanes show the PCR reaction number.

a) homozygous normal for both IVSI-6 $(\mathrm{T} \rightarrow \mathrm{C})$ and IVSI-110 $(\mathrm{G} \rightarrow \mathrm{A})$

b) heterozygous for IVSI-6 $(\mathrm{T} \rightarrow \mathrm{C})$ and homozygous normal for IVSI-110 $(\mathrm{G} \rightarrow \mathrm{A})$

\section{Discussion}

Palestine is one of the Mediterranean basin countries in which thalassemias are prevalent, however, few studies have been conducted on the disease. Sirdah et al. (1998) showed that the overall prevalence of $\beta$-thalassemia in the Gaza Strip area was $4.3 \%$. Occurrence of hereditary hemochromatosis among $\beta$-thalassemia intermediate and $\beta$-thalassemia minor subjects in Gaza Strip was assessed by Harara, 2006 [14]. In addition, immunological assessment of $\beta$-thalassemic major children aged 5 to 12 years old attending Abd El-Aziz El-Rantisy hospital in Gaza Strip was performed only recently [15].

However, no previous study was conducted for detection of the prevalence of $\beta$-thalassemia minor. Therefore, this study is the first in this regard and will be useful in evaluation, control and prevention of $\beta$-thalassemia.

\subsection{Hematological Characteristics of the Study Groups}

The population screened in the present work showed a significantly altered hemogram specially with $\mathrm{HCT}, \mathrm{Hb}$ and related indices ( $\mathrm{MCV}$ and $\mathrm{MCH}$ ) and RDW between the two groups. Comparing our hematological findings shown in Table 4 with other studies, our calculated means are close to those reported by Zacharias Habib (2009) in Egypt [16]. The means reported in that study were: male 5.07, 87.82 and female 4.47,
84.4 for RBCs and MCV respectively and ours were: male $4.43,87.5$ and female: $4.19,87.5$ respectively. The mean of HCT for female was in good agreement with our female's HCT mean. However, the mean of HCT in the present study was lower than that had been reported in the Egyptian study funding for males. The $\mathrm{Hb}$ mean for both males and females was lower (15.35 for males and 13.00 for females).

Our results revealed that the mean of $\mathrm{Hb}, \mathrm{MCV}, \mathrm{MCHC}$, RDW and PLT in both groups similar to the results reported by Al-Sweedan et al., 2012 in Jordan[17]. Their reported WBC's mean for the two genders was slightly less.

\subsection{Hematological Reference Range of the Study Groups}

The results of this study can be regarded as normal reference values in the University College of Science and Technology being part of the Palestinian population. This study covered the entire age range 17 to 28 years in males and females and showed the value of hematological parameters and red cell indices. The reference range found in this study matched that reported in the Palestinian Clinical Laboratory Tests Guide (2005) by the Palestinian National Authority Ministry of Health except for $\mathrm{Hb}, \mathrm{MCV}, \mathrm{MCH}$ MCHC and RDW (Table 6).

Table 6. Hematological parameters comparison between current study and that reported by Palestinian Ministry of Health.

\begin{tabular}{lllll}
\hline \multirow{2}{*}{ Parameter } & \multicolumn{2}{l}{ Current study } & Ministry of Health report \\
\cline { 2 - 5 } & Males & Females & Males & Females \\
\hline $\mathrm{WBC} \times 10^{9} / \mathrm{L}$ & $3.80-11.20$ & $3.80-11.20$ & $4.60-11.00$ & $4.60-11.00$ \\
$\mathrm{RBC} \times 10^{12} / \mathrm{L}$ & $3.90-5.20$ & $3.46-5.07$ & $4.69-6.13$ & $4.10-5.50$ \\
$\mathrm{Hb}(\mathrm{g} / \mathrm{dL})$ & $12.70-15.90$ & $9.20-13.20$ & $13.50-17.50$ & $12.00-16.00$ \\
$\mathrm{HCT}(\%)$ & $35.00-43.20$ & $30.10-43.00$ & $43.50-53.70$ & $37.00-48.00$ \\
$\mathrm{MCV}(\mathrm{fl})$ & $66.06-95.60$ & $66.06-95.60$ & $80.00-100.00$ & $80.00-100.00$ \\
$\mathrm{MCH}(\mathrm{pg})$ & $21.10-31.23$ & $21.10-31.23$ & $27.00-31.20$ & $27.00-31.00$ \\
$\mathrm{MCHC}(\mathrm{g} / \mathrm{dL})$ & $28.70-34.60$ & $28.70-34.60$ & $31.00-35.00$ & $31.00-35.00$ \\
$\mathrm{PLT} \times 10^{9} / \mathrm{L}$ & $159.72-453.75$ & $159.72-453.75$ & $150.00-450.00$ & $150.00-450.00$ \\
RDW $\%$ & $10.50-14.20$ & $9.80-15.20$ & $11.50-14.50$ & $11.50-14.50$ \\
\hline
\end{tabular}




\subsection{B-globin Gene Mutation by Allele Specific PCR}

The Allele Specific PCR (ASPCR) is an amplification strategy in which a polymerase chain reaction primer is designed in such a way that it is able to discriminate among templates that differ by a single nucleotide residue. The main advantage of ASPCR is that the amplification step and the diagnostic steps are combined, in that the presence of an amplified product indicates the presence of a particular allele and vice versa. It is a very time-efficient method [18]. The system is simple and reliable. It clearly distinguishes heterozygotes at a locus from homozygotes for either allele [12].

The molecular screening protocol we followed, which included two common Middle Eastern HBB mutations, enabled us to identify the causative mutations in $\beta$-globin gene of the $\beta$-thalassemic carrier included in this work. Our study showed that the IVSI-6 $(\mathrm{T} \rightarrow \mathrm{C})$ which is the mutation that reduces the efficiency of splicing at the $5^{\prime}$ site was observed in two samples only. This mutation has the lowest frequency and concomitant to what had been reported in neighboring countries. IVSI-6 $(\mathrm{T} \rightarrow \mathrm{C})$ is the lowest prevalent mutation in Egypt (13.60\%), Lebanon (15\%), the pre 1948 Occupied Palestine areas (14.70\%), Syria (4\%), Jordan (6.60\%), Kuwait (7.30\%) and Saudi Arabia (7\%) [19]. ElGawhary et al., (2007) reported that IVSI-6 is more frequent than IVSI-110, but their study covered Fayoum in Upper Egypt, Cairo, Alexandria and Tanta in Lower Egypt and the Nile Delta. The proportion of IVS-I-6 $(\mathrm{T} \rightarrow \mathrm{C})$ was $36.30 \%$ and that of IVSI-110 $(\mathrm{G} \rightarrow \mathrm{A})$ was $25.8 \%$ [20].

The IVS-I-110 $(\mathrm{G} \rightarrow \mathrm{A})$ mutation that causes aberrant splicing of pre-mRNA and deficient beta-globin chain synthesis is the most prevalent mutation that reported in neighboring countries, in Egypt (33\%), Lebanon (33\%), Syria (24\%), Jordan (22\%), and Saudi Arabia (22\%) [19] and in the Palestinians living at West Bank where the IVS-I- $110(\mathrm{G} \rightarrow \mathrm{A})$ mutation showed a prevalence of $17.6 \%$ [21]. This mutation was not in our study and this may be attributed to the prevention methods that have been used to reduce the disease.

\section{Conclusions}

This study showed that there is no statistically significance for WBCs, RBCs, PLTs and MCHC between male and female with high mean value of WBCs and PLTs in female.

The hematological characteristics $\mathrm{Hb}, \mathrm{MCV}, \mathrm{MCH}$ and RDW measured in the present work revealed significant differences between males and females with P-value 0.02, $0.009,0.019$ and 0.001 respectively. The hemoglobin level in females was fund to be about $20 \%$ less than the level reported in males.

The present study estimated the hematological parameters reference range for the students of the University College of Science and Technology-Khan Younis, Palestine. The IVSI110 mutation was not found in our population while IVSI-6 mutation was detected only in 2 of the 12 isolated DNA samples and both were heterozygous. The results suggests regular screening for $\beta$-thalassemia carrier in habitants of the Gaza Strip in order to discover the prevalence of the different types of $\beta$-globin mutation among them.

\section{References}

[1] D. Weatherall and J. Clegg, "Inherited hemoglobin disorders: an increasing global health problem", Bull World Health Organ, 79(8), pp 704-712, 2001.

[2] M. Honarbakhshi and H. Rahmanpour, "The prevalence of thalassemia minor and recognize carriers for prevention of thalassemia in Tarem Oolia region", Scientific Journal of Zanjan Medical University, 1377(23), pp 21-27, 2012.

[3] S. Mok, M Imwong. and M. J. Mackinnon, "Artemisinin resistance in Plasmodium falciparum is associated with an altered temporal pattern of transcription", BMC Genomics, 12(3), pp 391-405, 2011.

[4] F. Collins and S. Weissman, "The molecular genetics of human hemoglobin", Progress in nucleic acid research and molecular biology, 31(8), pp 315-421, 1984.

[5] A. Cao and R. Galanello, "Beta-thalassemia", Genetics In Medicine, 12(2), pp 61-76, 2010.

[6] P. Lahiry, S. Al-Attar and R. Hegele, "Understanding betathalassemia with focus on the Indian Subcontinent and the Middle East", Hematology Journal, 2(1), pp 5-13, 2008.

[7] S. L. Thein, "Genetic modifiers of $\beta$-thalassemia", Hematologica, 124(3), pp 649-60, 2005.

[8] M. Valko, D. Leibfritz and J. Moncol, "Free radicals and antioxidants in normal physiological functions and human disease", The International Journal of Biochemistry \& Cell Biology, 39(1), pp 44-84, 2007.

[9] A. Ceriello, "Possible role of oxidative stress in the pathogenesis of hypertension", Review, Diabetes Care, 31(2), pp 181-184, 2008.

[10] R. Galanello, A. Mosca, R. Paleari, G. Ivaldi, P. Giordano, "The role of haemoglobin A2 testing in the diagnosis of thalassemias and related haemoglobinopathies", Journal of Clinical Pathology, 62(1), pp 13-20, 2009.

[11] D. Filon, V. Oron, R. Shawa, E. Elborno, K. Najjar, T. Tulchinsky, E. Rachmilewitz, D. Rund, A. Oppenheim, "Spectrum of $\beta$-thalassemia mutations in the Gaza Area", Human Mutation 5, pp 351-353, 1995.

[12] C. R. Newton, A. Graham and L. E. Heptinstall, "Analysis of any point mutation in DNA, the amplification refractory mutation system (ARMS)", Nucleic Acids Research,17(7), pp 2503-2519, 1989 .

[13] M. Sirdah, Y. Bilto, S. El-Jabour and K. Najjar, "Screening secondary school students in the Gaza Strip for $\beta$-thalassemia trait, Clinical and laboratory", Haematology, 20(5), pp 279283, 1998

[14] Z. Harara, "Occurrence of hereditary hemochromatosis among $\beta$-thalassemia intermediate and $\beta$-thalassemia minor subjects in Gaza Strip - Palestine", MSc thesis, Islamic University of Gaza, 2006 
[15] S. Elhams, "Immunological assessment of B-thalassemic major children aged 5-12 years old attending Abd El-Aziz ElRantisy Hospital in Gaza Strip", MSc Thesis, Islamic University of Gaza, Palestine, 2010.

[16] Z. Habib, "Hematological criteria in hemoglobinopathy-free adult Egyptians" Hereditas, 95(23), pp 331-332, 2009.

[17] S. Al-Sweedan, M. Alhaj, "The effect of low altitude on blood count parameters from the department of Pediatrics, Jordan University of Science and Technology, Irbid, Jordan", Hematology/Oncology and Stem Cell Therapy, 5(3), pp 158$161,2012$.

[18] L. Dennis, M. Tein, T. Lau, C. Haines, T. Leung, P. Poon, J. Wainscoat, P. Johnson, A. Chang, N. Hjelm, "Quantitative analysis of fetal DNA in maternal plasma and serum:
Implications for noninvasive prenatal diagnosis", The American Journal of Human Genetics, 62(4), pp 768-775, 1998.

[19] L. Zahed, "The spectrum of $\alpha$-thalassemia mutations in the Arab populations", Biomedicine and Biotechnology Journal, 1(3), pp 129-132, 2001.

[20] S. El-Gawhary, S. El-Shafie, M. Niazi, M. Aziz, A. ElBeshlawy, "Study of $\beta$-thalassemia mutations using the polymerase chain reaction-amplification refractory mutation system and direct DNA sequencing techniques in a group of Egyptian thalassemia patients", Hemoglobin, 31(1), pp 63-69, 2007.

[21] H. Darwish, F. El-Khatib, S. Ayesh, "Spectrum of $\beta$-globin gene mutations among thalassemia patients in the West Bank region of Palestine", Hemoglobin, 29(2), pp 119-132, 2005. 